\title{
BALTO-SLAVIC PHONOLOGICAL DEVELOPMENTS
}

\author{
FREDERIK KORTLANDT
}

Elsewhere I have proposed the following relative chronology of early sound changes (1989a: 42-47, 2005a: 115-118):

(1) Neutralization of the opposition between palatovelars and labiovelars after ${ }^{*} u$ and ${ }^{*} s$, yielding a palatovelar before ${ }^{*} i$ and a plain velar elsewhere (cf. Steensland 1973: 34, Kortlandt 1979: 58). This development belongs to the Proto-IndoEuropean period (stages 1.2 and 1.3 of my chronology).

(2) Rephonemicization of the opposition between fortes ("voiceless") and lenes ("voiced aspirates") as an opposition between voiceless and (plain) voiced stops. This was a shared innovation of all Indo-European languages except Anatolian and Tocharian and therefore belongs to the dialectal Indo-European period (my stage 2.1). The (lenes) glottalic stops (traditionally called "plain voiced") became preglottalized voiced at this stage (cf. Kortlandt 1978a: 110).

(3) Retraction of ${ }^{*} s$ to ${ }^{*} s$ after ${ }^{*} i,{ }^{*} u,{ }^{*} r,{ }^{*} k$ in Balto-Slavic, Albanian, Armenian, and Indo-Iranian. The highly specific character of this sound change points to a common, dialectal Indo-European development (my stage 2.2).

(4) Depalatalization of the palatovelars before resonants unless the latter were followed by a front vowel, e.g. Slavic slovo 'word', Greek $\kappa \lambda \varepsilon$ ćs, but Lith. klausýti 'to listen' (cf. Kortlandt 1978b). This development was common to Balto-Slavic and Albanian and can therefore be dated to the end of the dialectal Indo-European period (my stage 2.3).

(5) Development of the palatovelars into palatal stops ("satemization"), e.g. ${ }^{\star} \hat{k}$ yielding ${ }^{*} \dot{c}$, which must evidently have been more recent than the depalatalization before resonants. The occlusive element appears to have been preserved before ${ }^{*} w$ in Polish dźwięk 'sound', dzwon 'bell', Ukr. dzvin, dzvir beside zvir 'beast', Mac. $d z v o n e c, d z v e r$, which shows that the palatal stops survived into Early Slavic.

(6) Rise of the lateral mobility in Balto-Slavic accent patterns. Here belong e.g. the rise of final stress in Lith. duktẽ 'daughter', piemuõ 'shepherd', sūnùs 'son', duodãss 'giving' and the retraction of the stress in acc.sg. dükteri, piemeni, diẽva

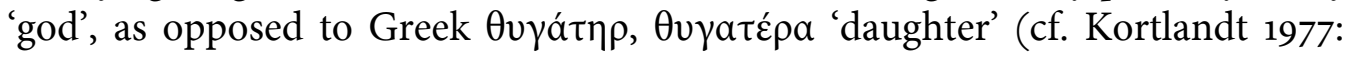


320f. and 2008a). These developments can be dated to the beginning of the Balto-Slavic period (my stages 3.1 through 3.4).

(7) Raising of final ${ }^{*}$-om to ${ }^{*}$-um (stage 3.6). This development was more recent than the substitution of the pronominal ending ${ }^{*}$-od in the nom.acc.sg. form of the oxytone neuter $o$-stems (stage 3.5). It is reflected in the Prussian ending -on $<{ }^{*}$-um $<{ }^{*}$-om in numerals and participles, e.g. dessìmton 'ten', mien Ismaitinton bhe perklantìton smunentien "mich verlornen vnnd verdampten Menschen", neuter billīton (20x), (po)dāton, (po)peisāton, pogalbton, poquoitìton, prolieiton, also acc.sg. deickton $(3 \times)$ 'thing, place', niainonton 'nobody', muisieson 'larger', pauson 'because', enterpon 'useful', pronominal gen.pl. stēison, steison, tennēison, tenneison, noūson, nouson, iouson (together $88 \times$ ), Lith. gen.pl. $-\boldsymbol{u}$, Slavic acc.sg. and gen.pl. $-\boldsymbol{z}$, also thematic aorist 1st sg. $-\boldsymbol{z}<{ }^{*}-u m<$ ${ }^{*}$-om, which remained distinct from $3 \mathrm{rd} \mathrm{pl.}-Q<{ }^{*}$-ont, so that the raising of

${ }^{*}$-om to ${ }^{*}$-um must have been earlier than the Balto-Slavic loss of final ${ }^{*}$ - $t$ /d (cf. Kortlandt 1978c: 287-290). The stem vowel of the $o$-stems was restored in Lith. acc.sg. $-a$ and in the Prussian nominal paradigm, where it was generalized and extended to the $\bar{a}$ - and $u$-stems (cf. Kortlandt 1988: 93f. and 1998: 125f.).

(8) Loss of final ${ }^{*}-t / d$ (stage 3.7$)$.

(9) Hirt's law: retraction of the stress if the vowel of the pretonic syllable was immediately followed by a laryngeal, e.g. Lith. dúona 'bread', výras 'man', dūmai 'smoke', Vedic dhānấs, vîrás, dhūmás, also Slovene dat.pl. goràm 'mountains', loc.pl. goràh, where the stress was retracted from the ending to the vowel before the stem-final laryngeal (stage 4.1). The stress was not retracted if the laryngeal followed the second component of a diphthong, as in Latvian tiêvs 'thin' $<{ }^{\star}$ tenHuós, or preceded the syllabic nucleus, as in Russian pilá '(she) drank' < ${ }^{\star} p H i l a ́ H$. The stress was not retracted to a lengthened grade vowel, as is clear

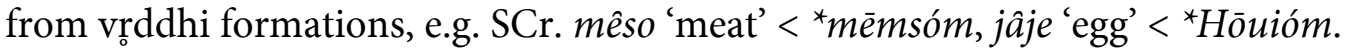
It follows that the laryngeals were still segmental phonemes at this stage. The retraction under discussion was more recent than the rise of final stress in Lith. inst. sūnumi, sūnumis because accentual mobility was preserved in SCr. sin 'son', where the stress was never retracted in the numerous trisyllabic case forms of the $u$-stem paradigm. Hirt's law was also more recent than the substitution of the pronominal ending in the oxytone neuter $o$-stems (stage 3.5) because neuters with retracted stress did not join the masculine gender, e.g. SCr. jäto 'flock', Vedic yātám.

(10) Dissolution of the syllabic resonants into a vocalic and a consonantal part, the former of which merged with ${ }^{*} u$ after the labiovelar stops and with ${ }^{{ }^{*}} i$ elsewhere (stage 4.2). This distribution was reshuffled under the influence of apophonic relationships. The labiovelars subsequently lost their labialization. The loss of the syllabic resonants was more recent than Hirt's law because the stress 
was retracted in Latvian i igs 'long', pĩns 'full', SCr. düg, pün, Vedic dīrghás, pürnás. It was also more recent than the dialectal Indo-European loss of the laryngeals before word-final nasals, e.g. in Lith. acc.sg. rañkg 'hand' $<{ }^{*}$-a $m<$ *aHm (cf. Kortlandt 2005b: 153f.).

(11) Winter's law: dissolution of the preglottalized voiced stops into a laryngeal and a buccal part (stage 4.3). The former merged with the reflex of the ProtoIndo-European laryngeals and the latter with the reflex of the lenes stops. Winter's law was more recent than the loss of final ${ }^{*} d(8)$ in view of the Slavic neuter pronoun to $<{ }^{*}$ tod. It was more recent than Hirt's law (9) because the stress was not retracted in Latvian pệds 'footstep' < ${ }^{*}$ pedóm, nuôgs 'naked' < ${ }^{*}$ nog ${ }^{w} o$ s, duômu '(I) give' $<{ }^{\star}$ dodHmí, where the broken tone reflects final stress. It was probably more recent than the loss of the syllabic resonants (10) because it was blocked in the cluster ${ }^{\star} n g n$ which arose as a result of the latter development in OCS. ognjb, Lith. ugnis 'fire' < ${ }^{*} n g^{w} n i$ (cf. Kortlandt 1979: 60).

(12) Retraction of the stress from final open syllables of disyllabic word forms unless the preceding syllable was closed by an obstruent (stage 4.4). This retraction was more recent than the loss of final ${ }^{*}-t / d(8)$, as is clear from Lith. gen.sg. vilko 'wolf $<{ }^{*}$-o d and SCr. aor. 3sg. nëse 'carried' $<{ }^{*}$-et. The stress was regularly retracted from final vowels, as in Ru. pílo '(it) drank', and diphthongs, as in Lith. dat.sg. vi $\tilde{l}_{k u i}$ 'wolf $<{ }^{*}-\bar{o} i$, gálvai 'head' $<{ }^{*}-\bar{a} i$, but not from syllables which ended in a fricative, a nasal, or a laryngeal, e.g. Lith. gen.sg. aviẽs 'sheep', gen.pl. vilkü 'wolf < ${ }^{*}$-om, nom.sg. galvà 'head' < ${ }^{*}-a H$, Ru. pilá '(she) drank'. It follows that word-final nasals and laryngeals were still ordinary consonants at this stage. The retraction was more recent than Hirt's law (9) because the accentual mobility in Ru. dalá, dálo '(she, it) gave', which must have arisen at this stage, presupposes an earlier end-stressed paradigm. If the word contained a full grade root vowel at the time of Hirt's law, retraction of the stress would have prevented the rise of accentual mobility. Thus, we have to assume that the full grade replaced earlier zero grade at a stage between Hirt's law and the retraction in dálo. The retraction was more recent than Winter's law (11) because the laryngeal feature of the preglottalized stops merged with the reflex of the ProtoIndo-European laryngeals at a stage between Hirt's law and the retraction. This can be deduced from the retracted stress of Ru. éla '(she) ate', séla '(she) sat down', which must have arisen from an analogical extension of Hirt's law. This retraction cannot have been phonetic in view of Lith. édąs 'eating', duodãs 'giving'. The analogical development must have been earlier than the retraction under discussion because the stress was not retracted in Ru. pilá 'drank', dalá 'gave'. In particular, it must have been earlier than the introduction of full grade in the root syllable of the latter form. 
(13) Rounding of ${ }^{*} e$ to ${ }^{*} o$ before intervocalic ${ }^{\star} w$, e.g. Slavic dat.sg. synovi $<$ ${ }^{*}$-euei, nom.pl. synove <*-eues (cf. Kortlandt 1979: 57). This development was more recent than the satemization which affected slovo 'word', Greek $\kappa \lambda \varepsilon$ ćç.

(14) Development of ${ }^{*} \mathrm{eu}$ to ${ }^{*}$ iou before consonants (cf. Pedersen 1935), e.g. in Slavic ljudije, Lith. liáudis 'people'. This sound change must have been more recent than the restoration of the front vowel in the cardinal devyni, Slavic devęts 'nine', replacing ${ }^{*}$ nowin $<{ }^{*} H_{1}$ neun on the basis of the ordinal ${ }^{\star}$ neuno-, which was subsequently replaced by ${ }^{\star}$ newino-, later ${ }^{\star}$ newinto- on the basis of the new cardinal ${ }^{\star}$ newin (cf. Hamp 1976). The vocalism of Lith. naũjas 'new' and kraũjas 'blood' is a resyllabification of ${ }^{\star}$ nowios and ${ }^{\star} k$ krowiom, as is clear from Sanskrit návyas, kravyám, Old Irish nuë.

(15) Prussian newints 'ninth' shows that the substitution of de- for ne- in Lith. devyni and Slavic devęto belongs to the dialectal Balto-Slavic period.

(16) Loss of final ${ }^{*}-r,{ }^{*}-n$ after a long vowel, e.g. Slavic mati 'mother', kamy 'stone', Lith. móté, akmuõ, Greek $\mu \eta \dot{\tau \eta \rho, ~ a ̈ \kappa \mu \omega v . ~ T h i s ~ d e v e l o p m e n t ~ w a s ~ m o r e ~}$ recent than the Slavic raising of ${ }^{*} \bar{e}$ and ${ }^{*} \bar{o}$ before the final resonant (stage 5.1) and therefore belongs to the dialectal Balto-Slavic period.

(17) Rounding of ${ }^{*} a,{ }^{*} \bar{a}$ and merger with ${ }^{*} O,{ }^{*} \bar{o}$ (stage 5.2), rise of nasal vowels (stage 5.5), rise of $x<{ }^{*} s$ (stage 5.7), rise of $s, z<{ }^{*} c^{\prime}$, ${ }^{*} 3$ (stage 5.8), vowel raising in the original endings inst.pl. ${ }^{*}-\bar{o} i$, acc.pl. ${ }^{*}$-ons and ${ }^{*}$-aHns to ${ }^{*}-\bar{u}$, later $-y$ (stage 5.9), and unrounding of ${ }^{*} O,{ }^{*} \bar{o}$ to ${ }^{*} a,{ }^{*} \bar{a}$ (stage 5.12). These developments were limited to Slavic, perhaps with the exception of the early rounding of ${ }^{*} a,{ }^{*} \bar{a}$ and their merger with ${ }^{{ }^{*}} 0,{ }^{\star} \bar{o}$, which was shared by Prussian and may therefore have been a dialectal Balto-Slavic innovation.

(18) Monophthongization of stressed ${ }^{*} e i,{ }^{*} a i,{ }^{*} \mathrm{O} i$ to ${ }^{*} \bar{e}$ in East Baltic (stage 3.1 of Kortlandt 1977: 323). As a result of this development, the vowel system changed from triangular to quadrilateral and thereby entailed a shift in the ablaut relations. In unstressed syllables, ${ }^{\star} \bar{a}$ and ${ }^{\star} \bar{o}$ merged, e.g. Lith. dovanà 'gift, present' and gen.sg. $-o<^{*}-\bar{o} d$. At the same time phonemic length was lost in diphthongs, e.g. dat.sg. mer̃gai 'girl', vilkui 'wolf, inst.pl. vilkaĩs. Short ${ }^{\star} o$ was unrounded and merged with ${ }^{*} a$.

(19) Rise of nasal vowels in East Baltic, e.g. Lith. kásti 'to bite', kęsti 'to suffer' (stage 3.2 of Kortlandt 1977: 324). At the same time, the glottal stop which continued the Proto-Indo-European laryngeals and the laryngeal feature of the preglottalized stops became a feature of the preceding vowel and developed into a broken tone. At a later stage, retractions of the stress resulted in rising and falling tone movements in the East Baltic dialects (cf. Kortlandt 2008a).

(20) In Slavic, the glottal stop which developed from the laryngeals and from the preglottalized stops was lost first in pretonic and post-posttonic syllables 
(stage 5.3), then in the remaining posttonic syllables (stage 7.13), at some stage became a feature of the preceding vowel yielding a broken tone, and was eventually lost in stressed syllables yielding a short rising tone (stage 9.2). The glottalization had been preserved in Russian at the time of the earliest borrowings into Latvian, where it is reflected as a stretched tone, e.g. miẽsts 'hamlet', muõka 'torment', grãmata 'book', kaĩps 'servant', as opposed to the falling tone reflecting the absence of glottalization in grẹ̀ks 'sin', bẹ̀da 'care', stràdât 'to work', svẹ̀ts 'holy', grẹ̀da 'pile', vèsts 'news' (cf. Kortlandt 2008a).

Thus, I think that the developments (2)-(4) were dialectal Indo-European, (6)-(14) were Proto-Balto-Slavic, and (17)-(20) belonged to the separate Slavic and East Baltic proto-languages.

Ranko Matasović has recently presented a relative chronology of Balto-Slavic sound changes (2005) which is in partial agreement with mine. It is therefore appropriate to discuss the differences between the two. These are the following:

(i) Matasović dates the depalatalization of palatovelars before resonants (4) and the satemization (5) before the retraction of ${ }^{*} s$ to ${ }^{*} s$ after ${ }^{*} i,{ }^{*} u,{ }^{*} r,{ }^{*} k$ (3) in spite of the fact that the latter was a shared development of Balto-Slavic, Albanian, Armenian and Indo-Iranian whereas the depalatalization before resonants was common to Balto-Slavic and Albanian (cf. Kortlandt 1978b: 242). He claims that Slavic osb 'axis' and desnz, desbnz 'right', as opposed to Sanskrit ákșas and dákșinas, Avestan aša- and dašina-, point to satemization before retraction of ${ }^{{ }^{*}}$. This idea is unfounded because there is no reason to suppose that ${ }^{*} \dot{c} s$ should yield $x$ rather than $s$ in Slavic, where ${ }^{*} s$ became $s$ before consonants, e.g. iskati 'to seek', voskz 'wax', jasnz 'clear', rěsnz 'distinct', suffix -bskz, Lith. ieškóti, vãškas, áiškus, ráiškus, -iškas, cf. also Alb. djathtë 'right', where th is identical with the phonetic reflex of ${ }^{\star} \hat{k}$, and the different simplifications in SCr. müšk $\bar{\imath}$ and Polish męski of the cluster attested in Russian mužskój 'masculine'. For Lith. vãškas, Slavic voskz, German Wachs, I have proposed to reconstruct ${ }^{*}$ uoksko- (1979: 59).

(ii) Matasović thinks that the depalatalization of palatovelars before resonants (4) was limited to the position before ${ }^{*} r,{ }^{*} l,{ }^{*} m$ followed by back vowels, e.g. Lith. akmuõ 'stone', Sanskrit áśmā, and did not affect palatovelars before ${ }^{\star} w$ and ${ }^{\star} n$, e.g. Lith. šuo 'dog', Sanskrit śvā < ${ }^{*} \hat{k} u \bar{o} n$, and Slavic znati 'to know' < * *onō-, Latin -gnōscō. In fact, these words reflect the antevocalic development of the

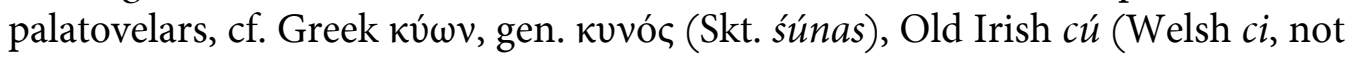
${ }^{* *}$ pi), Lith. žinóti, pažinti, žénklas 'sign', Slavic *zbnamb 'I know' (cf. Kortlandt 1985a). There can be no doubt that the palatovelars were depalatalized before ${ }^{\star} w$ followed by a back vowel in view of Polish kwiat 'flower', gwiazda 'star', Czech květ, hvězda, Skt. śvetás 'white', Greek poĩßoc 'bright' (cf. Pedersen 1926: 74), Prussian pecku 'cattle', Skt. paśús, gen. paśvás < ${ }^{\star}$ peḱkwos (cf. Kortlandt 1978b: 
241). There are no decisive examples of palatovelars before ${ }^{\star} n$ plus back vowel, but depalatalization must clearly have taken place in Lith. gentis 'tribe' beside žéntas 'son-in-law' and in Slavic ' ${ }^{*} Q \mathrm{qs} b$ beside Lith. žasis 'goose' (cf. Kortlandt 1985b: 119), as in Russian žëltyj 'yellow' beside zóloto 'gold' and zelënyj 'green', Lith. géltas, žélti, žãlias, which point to original depalatalization before syllabic resonants.

(iii) Matasovic has recently (2004) challenged the classic view that the phonetic reflex of the syllabic resonants is ${ }^{*} u R$ after original labiovelar stops and ${ }^{*} i R$ elsewhere (Vaillant 1950: 167-177, Stang 1966: 82). I have argued that the new proposal is mistaken and that we have to return to the classic theory, which remains unsurpassed (2007a). It follows that the delabialization of the labiovelars cannot have preceded the dissolution of the syllabic resonants into a vocalic and a consonantal part (10).

(iv) Matasović has an idiosyncratic view of Winter's law (11). He claims that "vowels were lengthened before PIE voiced consonants in closed syllables" before the "aspirated stops" merged with the "voiced stops" in Balto-Slavic, concluding that the latter development was "independent of the similar processes in Celtic, Germanic, and Albanian" (2005: 151). This view cannot be correct (cf. Derksen 2002 and Kortlandt 2008b, also Dybo 2002). For Lith. dubùs 'deep', gegužẽ 'cuckoo', Slavic kobb 'augury' (rather than "destiny”), Matasović adduces Germanic cognates, which are inconclusive (cf. Lühr 1988, Kortlandt 1991). For Lith. kadà 'when' I refer to Derksen (2002: 11f.) and for ligà 'disease' to Dybo (2002: 503-505) while smagùs 'heavy' cannot be separated from smagùs 'pleas-

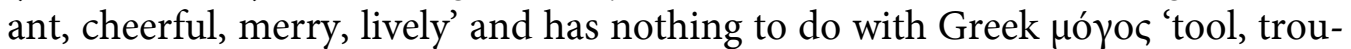
ble, distress'. Lith. pãdas 'sole' and Slavic podz 'floor' cannot be separated from Lith. iñdas 'dish', iždas 'treasury', priẽdas 'addition', etc. and must be derived from ${ }^{*} \operatorname{pod}^{h} \mathrm{H}_{1} \mathrm{O}$-, cf. also padéklas 'tray', padëti 'to put', not from the etymon of Greek $\pi \varepsilon$ $\delta$ ov 'ground, earth' (cf. already Winter 1978: 439). Matasović objects to the "use of forms with a nasal infix, which, in [FK's] opinion, blocked the operation of Winter's law, to account for the lack of lengthening in forms where no infix is attested" (2005: 155). This is completely wrong. Polish sięgać (not "sę$\left.g a c^{\prime \prime}\right)$ 'to reach' does not have an infixed but a radical nasal, cf. Sanskrit perfect sasañja, aorist asañji, infinitive sankktos, desiderative sisañkșati, causative sañjayati of the zero grade root saj- 'hang', German Senkel 'lace', with regular operation of Winter's law in SCr. sëzati, Czech sahati, also Polish siegać, but loss of the acute before the nasal suffix which blocked Winter's law in SCr. ségnuti, Czech sáhnouti < ${ }^{*}$-ngn-, as in Lith. ugnis < ungnis, Slavic ognjo 'fire'. The unavoidable conclusion is that the radical nasal attested in Indo-Iranian, Slavic and Germanic was eliminated in Lith. sègti 'to fasten', probably because it was reanalyzed as an inappropriate nasal infix. Matasović "fail[s] to understand how a form like OCS xodz 'walk' can be built on the analogy with the reduplicated 
present ${ }^{*}$ si-sd-o-" (ibidem) but does not mention the preterit stem šbd- 'went' (cf. also Kortlandt 1989b). Matasović disregards the evidence for preglottalized voiced stops in Latin (Lachmann's law), Germanic (cf. Kortlandt 2007b), Greek (cf. Kortlandt 1983a), and Indo-Iranian (cf. Kortlandt 1985c: 192f.). He does not discuss the absence of evidence for "voiced aspirates" in Proto-Indo-European (cf. Kortlandt 2007c: 149-151). Perhaps most striking is his disregard of the fact that long vowels from Winter's law did not merge with earlier long vowels in Balto-Slavic (cf. Kortlandt 1985b) and that glottalization was preserved until after the rise of the new timbre distinctions in Slavic, as is clear from Upper Sorbian stódki 'sweet', where the acute from Winter's law lengthened the root vowel, as opposed to Polish słodki. The glottalization has been preserved up to the present day in Latvian pệds 'footstep', nuôgs 'naked', as in British English foot, naked (cf. Andrésen 1968).

(v) Matasović dates the Slavic rounding of ${ }^{\star} a$ to ${ }^{*} O$ (17) and the East Baltic unrounding of ${ }^{*} o$ to ${ }^{\star} a(18)$ to the Balto-Slavic period because "it is more economical to assume that the merger of short ${ }^{*} a$ and ${ }^{*} o$ was a common Balto-Slavic innovation" (2005: 151). This presupposition does not explain why we find e.g. Lith. inst.pl. vilkaĩs 'wolves' < ${ }^{*}$-öis with delabialization versus Slavic acc.pl. ženy 'women' $<{ }^{*}$-ons $<{ }^{*}$-aHns with raising of the rounded vowel. Similarly we have raising in Slavic kamy 'stone', Lith. akmuõ, which shows that Slavic voda 'water' $<{ }^{*}$ wundaH must be compared with Prussian wundan, unds, Latin unda < ${ }^{*} u n d n-<{ }^{*} u d n$-, not with Lith. vanduõ, Latvian $\hat{u} d e n s$ (with an acute from Winter's law, cf. Kortlandt 1979: 61).

(vi) Matasović thinks that the Proto-Indo-European laryngeals were lost after resonants with "compensatory lengthening of the preceding syllable, which received the Balto-Slavic acute”, e.g. Lith. árklas 'plough' < ${ }^{\star}$ arrtlo- $<{ }^{\star} \mathrm{H}_{2} \mathrm{erH}_{3}$ tlo-,

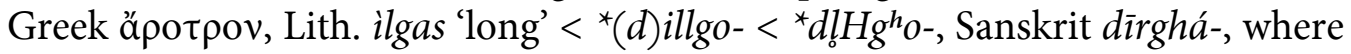
the acute "could have been just a feature of vowels at this stage, presumably glottalization" (2005: 152). If we take the latter statement seriously, we have to reconstruct Proto-Balto-Slavic *ảrtlo and ${ }^{*}$ dilgos, cf. SCr. rälo, düg, without compensatory lengthening. This puts the loss of the laryngeals in East Baltic (19) and Slavic (20) well after the end of the Balto-Slavic period. Indeed, glottalization has been preserved until today in Latvian ârkls and was preserved until after the rise of pleophony (polnoglasie) in Ukrainian moró $z$ 'frost', where the acute remained distinct both from the falling tone in acc.sg. hólovu 'head' and from the rising tone in gen.pl. holiv of the same word. The inescapable conclusion is that the laryngeals were not lost in Balto-Slavic times. In fact, the late Balto-Slavic retraction of the stress from final open syllables (12) shows that the laryngeals behaved like regular consonants until the end of the Balto-Slavic period. There are no instances of acute vrddhi formations in Balto-Slavic (cf. Kortlandt 1985b: 121). 
(vii) Matasović does not accept my Balto-Slavic raising of final ${ }^{*}$-om to ${ }^{*}$-um (7). Unfortunately, he does not tell his readers how he accounts for the Prussian ending -on instead of -an in dessimton, ismaitinton, perklantìton, billiton, (po)dāton, (po)peisāton, pogalbton, poquoitīton, prolieiton, deickton, niainonton, muisieson, pauson, enterpon, stēison, tennèison, noūson, iouson, as opposed to the regular acc.sg. and gen.pl. ending -an, for the preservation of the difference between the Slavic thematic aorist endings 1st sg. $-\mathfrak{b}<{ }^{*}$-om and 3rd pl. $-Q<$ ${ }^{*}$-ont when final ${ }^{*}-t$ was lost (8), and for the merger of the pre-Hirt barytone neuter $o$-stems with the masculines in Slavic (cf. Illič-Svityč 1963: 119), Latvian (cf. Kortlandt 1982: 6), Lithuanian (cf. Kortlandt 1993), and Prussian (cf. Kortlandt 1983b: 183). Whether or not Matasović and others accept my views is of no interest to me. The only interesting matter is how they account for the evidence which I have adduced. There is no point in expressing an opinion without discussing the evidence.

I conclude that Matasović's considerations have given me no reason to change my opinion on any of the issues under discussion.

\section{Leiden University}

\section{REFERENCES}

Andrésen, Bjørn S.

1968 Pre-glottalization in English standard pronunciation. Oslo: Norwegian UP.

Derksen, Rick

2002 "On the reception of Winter's law". Baltistica 37/1, 5-13.

Dybo, Vladimir A.

2002 "Balto-Slavic accentology and Winter's law". Studia Linguarum 3/2, 295-515.

Hamp, Eric P.

1976 "On Slavic ev < ${ }^{*}$ eu”. Zbornik za Filologiju i Lingvistiku 19/2, 13-14.

Illič-Svityč, Vladislav M.

1963 Imennaja akcentuacija $v$ baltijskom i slavjanskom: Sud'ba akcentuacionnyx paradigm. Moskva: AN SSSR.

Kortlandt, Frederik.

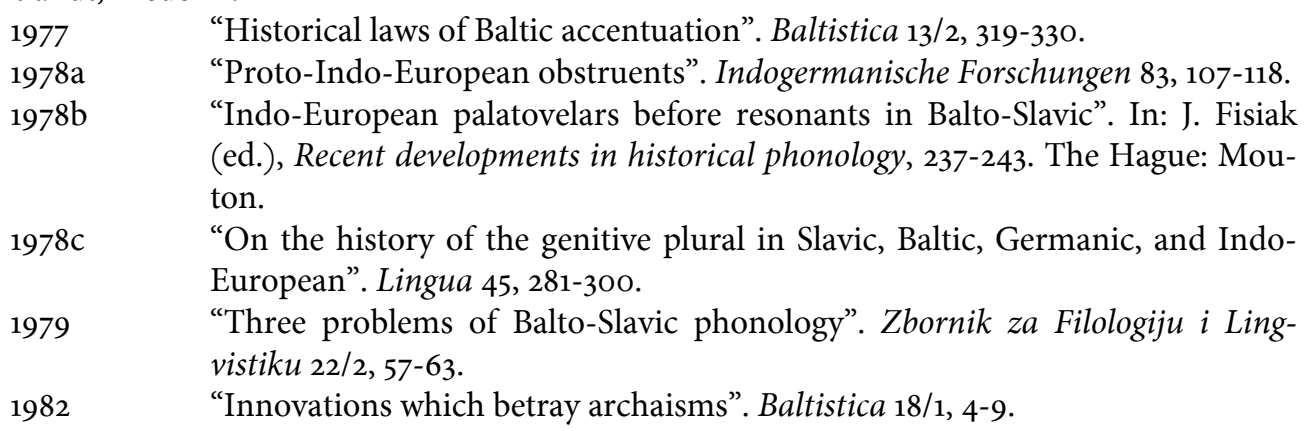


1983a “Greek numerals and PIE glottalic consonants". Münchener Studien zur Sprachwissenschaft 42, 97-104.

1983b "On final syllables in Slavic”. Journal of Indo-European Studies 11, 167-185.

1985a. "Slavic imamb". International Journal of Slavic Linguistics and Poetics 31-32, 235-239.

1985b "Long vowels in Balto-Slavic". Baltistica 21/2, 112-124.

1985 C "Proto-Indo-European glottalic stops: The comparative evidence". Folia Linguistica Historica 6/2, 183-201.

1988 "Van Wijk's Altpreussische Studien revisited". Studies in Slavic and General Linguistics 12, 89-97.

1989a “Od praindoevropskog jezika do slovenskog (fonološki razvoj)”. Zbornik za Filologiju i Lingvistiku 32/2, 41-58. [English edition: see www.kortlandt.nl/ publications]

$1989 \mathrm{~b} \quad$ "Lithuanian statýti and related formations". Baltistica 25/2, 104-112.

1991 "Kluge's law and the rise of Proto-Germanic geminates". Amsterdamer Beiträge zur älteren Germanistik 34, 1-4.

1993 “Tokie šalti rytai”. Baltistica 28/1, 45-48.

1998 "The language of the Old Prussian catechisms". Res Balticae 4, 117-129.

2005a "From Serbo-Croatian to Indo-European". Wiener Slavistisches Jahrbuch 51, 113-130.

2005b “Holger Pedersen's Études lituaniennes revisited”. Baltistica: VI priedas, 151-157.

2007a "The development of the Indo-European syllabic resonants in Balto-Slavic". Baltistica 42/1, 7-12.

$2007 \mathrm{~b} \quad$ "Proto-Germanic obstruents and the comparative method". North-Western European Language Evolution 52, 3-7.

$2007 \mathrm{C}$ Italo-Celtic origins and prehistoric development of the Irish language. Amsterdam: Rodopi.

2008a "Accent retraction and tonogenesis". In: Proceedings of the 2nd international workshop on Balto-Slavic accentology, forthcoming.

$2008 \mathrm{~b}$ "Winter's law again". In: Proceedings of the 3 rd international workshop on Balto-Slavic accentology, forthcoming.

Lühr, Rosemarie 1988 Expressivität und Lautgesetz im Germanischen. Heidelberg: Carl Winter. Matasović, Ranko

2004 "The Proto-Indo-European syllabic resonants in Balto-Slavic". Indogermanische Forschungen 109, 337-354.

2005 "Toward a relative chronology of the earliest Baltic and Slavic sound changes". Baltistica 40/2, 147-157.

Pedersen, Holger

1926 La cinquième déclinaison latine. København: Høst.

1935 "Lit. iau". Studi Baltici 4, 150-154.

Stang, Christian S. 1966 Vergleichende Grammatik der baltischen Sprachen. Oslo: Universitetsforlaget.

Steensland, Lars

1973 Die Distribution der urindogermanischen sogenannten Gutturale. Uppsala: UP.

Vaillant, André 1950

Grammaire comparée des langues slaves I: Phonétique. Lyon: IAC. 
Winter, Werner 1978

"The distribution of short and long vowels in stems of the type Lith. ésti : vèst $i$ : mèsti and OCS jasti : vest $i$ : mest $i$ in Baltic and Slavic languages". In: J. Fisiak (ed.), Recent developments in historical phonology, 431-446. The Hague: Mouton. 